Article

\title{
Antimicrobial Resistance, Virulence Factors, and Pathotypes of Escherichia coli Isolated from Drinking Water Sources in Jordan
}

\author{
Samer Swedan * (D) and Heba Abu Alrub \\ Department of Medical Laboratory Sciences, Jordan University of Science and Technology, Irbid 22110, Jordan; \\ htabualrub13@ams.just.edu.jo \\ * Correspondence: sfswedan4@just.edu.jo; Tel.: +962-27201000 (ext. 26886)
}

Received: 17 May 2019; Accepted: 21 June 2019; Published: 25 June 2019

\begin{abstract}
The study investigated the prevalence of potentially pathogenic and drug resistant Escherichia coli among drinking water sources in Jordan. A total of 109 confirmed E. coli isolates were analyzed. Antimicrobial susceptibility testing was done using the Kirby Bauer disk diffusion method. Phenotypic identification of extended spectrum beta-lactamase (ESBL) and carbapenemase production was done using the double disk synergy test and the modified Hodge test, respectively. Isolates' plasmid profiles were determined by gel electrophoresis. PCR was used for detection of virulence and resistance genes. Overall, $22.0 \%$ of the isolates were potentially intestinal pathogenic E. coli (IPEC); namely enteroaggregative E. coli (16.5\%), enteropathogenic E. coli (2.8\%), enteroinvasive E. coli $(1.8 \%)$, and enterohemorrhagic E. coli $(0.9 \%)$. A third of the isolates were multi-drug resistant. The highest rates of antimicrobials resistance were observed against ampicillin (93.6\%) and sulfamethoxazole/trimethoprim (41.3\%). All isolates were susceptible to imipenem, meropenem, doripenem and tigecycline. The prevalence of ESBL and carbapenemase producers was $54.1 \%$ and $2.8 \%$, respectively. Bla ${ }_{V I M}$ was the most prevalent resistance gene $(68.8 \%)$, followed by $b l a_{C T X}(50.5 \%)$, $b l a_{T E M}(45.9 \%), b l a_{N D M}(11 \%), b l a_{K P C}(4.6 \%)$, and bla $a_{S H V}(0.9 \%)$. Fifty-eight $(53.2 \%)$ isolates contained one or more plasmid ranging from 1.0 to $8.0 \mathrm{kbp}$. Overall, high prevalence of potentially pathogenic and resistant isolates was observed.
\end{abstract}

Keywords: Escherichia coli; pathotype; resistance; antibiotic; beta lactamase; carbapenemase; plasmid

\section{Introduction}

Diarrheal diseases are considered major infectious diseases leading to high rates of morbidity and mortality worldwide [1]. Diarrheal diseases occur more commonly in developing countries and particularly among children, in which diarrhea is considered the second-most common cause (after pneumonia) of death under the age of five [2]. The lack of safe water supplies, use of contaminated water sources, inadequate sanitation, and poor hygiene are the main risk factors for acquiring diarrhea in developing countries [2].

Most of the known E. coli strains are members of the gut normal flora. However, some strains are considered true pathogens, capable of causing urinary tract infections, sepsis, meningitis, and enteric or diarrheal diseases [3]. E. coli is an etiologic agent of diarrhea in developing countries. It is responsible for major waterborne bacterial infections and is successfully transmitted through the direct intake of contaminated water or indirectly through food crops exposed to contaminated water sources [3]. Diarrheagenic E. coli strains also known as intestinal pathogenic E. coli (IPEC) have been grouped into six pathotypes: Enteropathogenic E. coli (EPEC), enterotoxigenic E. coli (ETEC), enterohemorrhagic E. coli (EHEC), enteroinvasive E. coli (EIEC), enteroaggregative E. coli (EAEC), and 
diffusely adherent E. coli (DAEC) [4]. These strains contain virulence genes which can be used for strain identification. The virulence genes are encoded on mobile genetic elements which enable their spread to other bacteria [5].

The attaching and effacing gene (eae) is found in EPEC and EHEC. This gene is associated with the development of attaching and effacing lesions in the intestinal epithelium $[5,6]$. The EAEC which usually causes persistent diarrhea can be identified by detection of the AggR-activated island (aaiC) gene $[5,7]$. The EHEC causes severe diseases such as bloody diarrhea and hemolytic uremic syndrome due to the release of shiga toxin [8]. The production of shiga toxins encoded on stx1 and/or st $x 2$ genes is what distinguishes EHEC from other E. coli pathotypes, such as EPEC [5]. The EIEC is similar to Shigella spp. in multiple aspects such as the invasion of the colon, and is usually characterized by the presence of the ipaH gene [3,5].

The recent rise in antimicrobial resistance rates among E. coli is significantly contributing to treatment difficulties and failures leading to increased morbidity and mortality among patients [9]. Some of the mechanisms of resistance include the production of extended-spectrum lactamases (ESBLs) and carbapenemases. ESBLs are plasmid-mediated enzymes having the ability to hydrolyze beta-lactam antimicrobial agents including penicillins, cephalosporins, and aztreonam. ESBLs can be classified into three main types; TEM, SHV, and CTX-M [10,11]. Carbapenemases are a major group of beta-lactamases capable of hydrolyzing penicillins, cephalosporins, monobactams, and carbapenems. They include beta-lactamases of classes B (e.g., IMP and VIM), D (e.g., OXA-23 to -27), and A (e.g., IMI, KPC, NMC, and SME) [12,13].

The contamination of the water supply with pathogenic E. coli strains is a serious risk factor for spreading waterborne infections in humans [14]. On the other hand, the presence of resistant $E$. coli strains in the water supply and the emergence of antimicrobial resistance mechanisms, especially those associated with mobile genetic elements, may enhance the possibility of simultaneous spreading of antimicrobial resistance and virulence genes to other bacteria, leading to the emergence of resistant pathogens [15].

Knowledge about the prevalence of pathogenic E. coli strains among sources of the drinking water supply in Jordan and in many developing countries is lacking. In this study, we identified the prevalence of potentially IPEC among drinking water sources in Jordan, antimicrobial susceptibility genotypes and phenotypes, and bacterial plasmid profiles. Overall, $22.0 \%$ of the E. coli isolates were potentially pathogenic strains. Multi-drug resistance, ESBL production, and carbapenemase production, were observed among the isolates at different rates. This and other similar studies [4,16-19], enable policy makers to undertake necessary actions to improve water safety via monitoring the occurrence of serious pathogens and drug resistance.

\section{Results}

\subsection{Identification of E. coli Pathotypes}

Among 109 confirmed E. coli isolates recovered from drinking water sources, 24 (22.0\%) were potentially IPEC, as determined by the presence of characteristic virulence genes. The majority of the potentially pathogenic isolates $(16.5 \% ; 18 / 109)$ were EAEC which were positive for either aat $(12.8 \%$; $14 / 109)$ or aaic $(2.8 \% ; 3 / 109)$, or both genes $(0.9 \% ; 1 / 109)$, followed by EPEC which were positive for eae and negative for $s t x 1$ and stx $2(2.8 \% ; 3 / 109)$, EIEC which were positive for ipaH $(1.8 \% ; 2 / 109)$, and one isolate was putatively considered EHEC as it was positive for stx 1 but surprisingly negative for eae $(0.9 \% ; 1 / 109)$. None of the isolates were positive for $s t x 2$. The remaining isolates $(78.0 \% ; 85 / 109)$ lacked any of the investigated virulence genes.

\subsection{Antimicrobial Susceptibility}

The antimicrobial susceptibility profile of the isolates to various antimicrobial agents is shown in Table 1. The highest rates of resistance were observed against ampicillin (93.6\%), followed 
by sulfamethoxazole/trimethoprim $(41.3 \%)$, ciprofloxacin $(16.5 \%)$, levofloxacin $(14.7 \%)$, ceftriaxone/ cefotaxime $(12.9 \%)$ and ceftizoxime (9.2\%). All isolates were sensitive to imipenem, meropenem, doripenem and tigecycline. Resistance to three or more of the antimicrobial agent groups i.e., multi-drug resistance (MDR) phenotype, was seen among 34.9\% of the isolates (Table 2).

Table 1. Antimicrobial susceptibility results.

\begin{tabular}{cccc}
\hline Antimicrobial Agent & $\begin{array}{c}\text { Susceptible } \\
\text { Number (\%) }\end{array}$ & $\begin{array}{c}\text { Intermediate } \\
\text { Number (\%) }\end{array}$ & $\begin{array}{c}\text { Resistant } \\
\text { Number (\%) }\end{array}$ \\
\hline Amoxicillin/clavulanic acid & $80(73.4)$ & $22(20.2)$ & $7(6.4)$ \\
Aztreonam & $97(89)$ & $4(3.7)$ & $8(7.3)$ \\
Cefotaxime & $94(86.2)$ & $1(0.9)$ & $14(12.9)$ \\
Ceftazidime & $98(89.9)$ & $5(4.6)$ & $6(5.5)$ \\
Ceftizoxime & $97(89)$ & $2(1.8)$ & $10(9.2)$ \\
Ceftriaxone & $94(86.2)$ & $1(0.9)$ & $14(12.9)$ \\
Ampicillin & $3(2.7)$ & $4(3.7)$ & $102(93.6)$ \\
Ciprofloxacin & $91(83.5)$ & 0 & $18(16.5)$ \\
Levofloxacin & $92(84.4)$ & $1(0.9)$ & $16(14.7)$ \\
Nitrofurantoin & $107(98)$ & $1(0.9)$ & $1(0.9)$ \\
Tigecycline & $63(57.8)$ & $1(0.9)$ & $45(41.3)$ \\
Doripenem & $109(100)$ & 0 & 0 \\
Ertapenem & $109(100)$ & 0 & 0 \\
Imipenem & $104(95.4)$ & $3(2.8)$ & $2(1.8)$ \\
Meropenem & $109(100)$ & 0 & 0 \\
& $109(100)$ & 0 & 0 \\
\hline
\end{tabular}

Table 2. Isolates' resistance to antimicrobial agent groups.

\begin{tabular}{ccc}
\hline Number of Antimicrobial Agent Groups & Number of Resistant Isolates & $\mathbf{\%}$ \\
\hline 0 & $2 *$ & 1.8 \\
1 & 52 & 47.7 \\
2 & 17 & 15.6 \\
3 & 21 & 19.3 \\
4 & 7 & 6.4 \\
5 & 5 & 4.6 \\
6 & 3 & 2.8 \\
7 & 2 & 1.8 \\
\hline
\end{tabular}

Note: ${ }^{*}$ The two isolates were susceptible to all tested antimicrobial agents.

Based on the results of the five antimicrobial agents used in the double disk synergy test (DDST) to detect ESBL producers, 59 ESBL producers were identified. Augmentation of the inhibition zone which indicates an ESBL producer was observed most frequently with ceftizoxime and cefotaxime (79.7\% each; 47/59), followed by aztreonam $(72.9 \% ; 43 / 59)$, ceftriaxone $(67.8 \% ; 40 / 59)$, and ceftazidime $(49.2 \% ; 29 / 59)$. The correlation between the ESBL phenotype and susceptibility to antimicrobial agents is shown in Appendix A. A significant association was observed between the ESBL phenotype and nonsusceptibility to amoxicillin/clavulanic acid, aztreonam, cefotaxime, ceftazidime, ceftizoxime, and ceftriaxone.

Based on the results of the four carbapenem drugs used in the modified Hodge test (MHT), three carbapenemase producing isolates were identified. The MHT positive isolates gave positive results only with ertapenem and imipenem (66.7\% each; $2 / 3)$. The correlation between the carbapenemase phenotype and susceptibility to antimicrobial agents is shown in Appendix B. A significant association was observed between the carbapenemase phenotype and nonsusceptibility to amoxicillin/clavulanic acid $(100 \% ; 3 / 3)$, aztreonam $(66.7 \% ; 2 / 3)$, cefotaxime $(66.7 \% ; 2 / 3)$, ceftazidime $(66.7 \% ; 2 / 3)$, ceftizoxime $(66.7 \% ; 2 / 3)$, and ceftriaxone $(66.7 \% ; 2 / 3)$. No significant association was observed between the carbapenemase and ESBL phenotypes (Table 3$)$. 
Table 3. Association between extended-spectrum lactamase (ESBL) and carbapenemase phenotypes.

\begin{tabular}{ccccc}
\hline \multirow{2}{*}{ Criteria } & & \multicolumn{2}{c}{ Carbapenemase Producer (Number) } & \multirow{2}{*}{$p$ Value } \\
\cline { 2 - 4 } & & No & Yes & \\
\hline ESBL Producer & No & 49 & 1 & \multirow{2}{*}{0.562} \\
(Number) & Yes & 57 & 2 & \\
\hline
\end{tabular}

\subsection{Beta-Lactamase Resistance Genes}

The beta-lactamase genes were detected among the isolates at the following rates: $b \operatorname{la}_{V I M}(68.8 \%$; 75/109), bla $a_{C T X}(50.5 \% ; 55 / 109), b l a_{T E M}(45.9 \% ; 50 / 109), b l a_{N D M}(11 \% ; 12 / 109), b l a_{K P C}(4.6 \% ; 5 / 109)$, and $b l a_{S H V}(0.9 \% ; 1 / 109)$. Co-associations were observed between $b l a_{K P C}$ and $b l a_{T E M}(p=0.018)$, while gene independence was observed between $b l a_{N D M}$ and $b l a_{V I M}(p=0.008)$ (Table 4). There were significant associations between stx1 with bla $a_{K P C}$, aaic with bla $a_{T E M}$, and aat with bla $a_{V I M}$ (Table 5). 
Table 4. Co-association of resistance genes.

\begin{tabular}{|c|c|c|c|c|c|c|c|c|c|c|c|c|c|}
\hline \multirow{2}{*}{\multicolumn{2}{|c|}{ Gene }} & \multicolumn{2}{|c|}{$b^{b l a}{ }_{K P C}$} & \multicolumn{2}{|c|}{$b^{b l a} a_{N D M}$} & \multicolumn{2}{|c|}{$b^{b l a}{ }_{V I M}$} & \multicolumn{2}{|c|}{$b l a_{T E M}$} & \multicolumn{2}{|c|}{$b l a_{S H V}$} & \multicolumn{2}{|c|}{$b l a_{C T X}$} \\
\hline & & Absent & Present & Absent & Present & Absent & Present & Absent & Present & Absent & Present & Absent & Present \\
\hline \multirow{3}{*}{$b l a_{K P C}$} & Absent & 104 & 0 & 93 & 11 & 32 & 72 & 59 & 45 & 103 & 1 & 53 & 51 \\
\hline & Present & 0 & 5 & 4 & 1 & 2 & 3 & 0 & 5 & 5 & 0 & 1 & 4 \\
\hline & $p$ Value & \multicolumn{2}{|c|}{-} & \multicolumn{2}{|c|}{0.448} & \multicolumn{2}{|c|}{0.499} & \multicolumn{2}{|c|}{0.018} & \multicolumn{2}{|c|}{0.954} & \multicolumn{2}{|c|}{0.187} \\
\hline \multirow{3}{*}{$b l a_{N D M}$} & Absent & 93 & 4 & 97 & 0 & 26 & 71 & 55 & 42 & 96 & 1 & 47 & 50 \\
\hline & Present & 11 & 1 & 0 & 12 & 8 & 4 & 4 & 8 & 12 & 0 & 7 & 5 \\
\hline & $p$ Value & \multicolumn{2}{|c|}{0.448} & \multicolumn{2}{|c|}{ - } & \multicolumn{2}{|c|}{0.008} & \multicolumn{2}{|c|}{0.110} & \multicolumn{2}{|c|}{0.890} & \multicolumn{2}{|c|}{0.368} \\
\hline \multirow{3}{*}{ bla $_{V I M}$} & Absent & 32 & 2 & 26 & 8 & 34 & 0 & 19 & 15 & 34 & 0 & 21 & 13 \\
\hline & Present & 72 & 3 & 71 & 4 & 0 & 75 & 40 & 35 & 74 & 1 & 33 & 42 \\
\hline & $p$ Value & \multicolumn{2}{|c|}{0.499} & \multicolumn{2}{|c|}{0.008} & \multicolumn{2}{|c|}{-} & \multicolumn{2}{|c|}{0.485} & \multicolumn{2}{|c|}{0.688} & \multicolumn{2}{|c|}{0.065} \\
\hline \multirow{3}{*}{$b a_{T E M}$} & Absent & 59 & 0 & 55 & 4 & 19 & 40 & 59 & 0 & 58 & 1 & 30 & 29 \\
\hline & Present & 45 & 5 & 42 & 8 & 15 & 35 & 0 & 50 & 50 & 0 & 24 & 26 \\
\hline & $p$ Value & \multicolumn{2}{|c|}{0.018} & \multicolumn{2}{|c|}{0.110} & \multicolumn{2}{|c|}{0.485} & & & & & & \\
\hline & Absent & 103 & 5 & 96 & 12 & 34 & 74 & 58 & 50 & 108 & 0 & 54 & 54 \\
\hline$b^{\prime l} a_{S H V}$ & Present & 1 & 0 & 1 & 0 & 0 & 1 & 1 & 0 & 0 & 1 & 0 & 1 \\
\hline & $p$ Value & & & & & & & & & & & & \\
\hline & Absent & 53 & 1 & 47 & 7 & 21 & 33 & 30 & 24 & 54 & 0 & 54 & 0 \\
\hline bla $_{C T X}$ & Present & 51 & 4 & 50 & 5 & 13 & 42 & 29 & 26 & 54 & 1 & 0 & 55 \\
\hline & $p$ Value & & & & & & & & & & & & \\
\hline
\end{tabular}


Table 5. Association between virulence and resistance genes.

\begin{tabular}{|c|c|c|c|c|c|c|c|c|c|c|c|c|}
\hline \multirow{2}{*}{\multicolumn{2}{|c|}{ Gene }} & \multicolumn{2}{|c|}{ eae } & \multicolumn{2}{|c|}{ aaic } & \multicolumn{2}{|c|}{ aat } & \multicolumn{2}{|c|}{ stx 1} & \multirow{2}{*}{$\begin{array}{c}\text { stx } 2 \\
\text { Absent }\end{array}$} & \multicolumn{2}{|c|}{ ipah } \\
\hline & & Absent & Present & Absent & Present & Absent & Present & Absent & Present & & Absent & Present \\
\hline \multirow{3}{*}{$b^{\prime} a_{K P C}$} & Absent & 101 & 3 & 100 & 4 & 89 & 15 & 104 & 0 & 104 & 102 & 2 \\
\hline & Present & 5 & 0 & 5 & 0 & 5 & 0 & 4 & 1 & 5 & 5 & 0 \\
\hline & $p$ Value & \multicolumn{2}{|c|}{0.867} & \multicolumn{2}{|c|}{0.827} & \multicolumn{2}{|c|}{0.470} & \multicolumn{2}{|c|}{0.046} & NA & \multicolumn{2}{|c|}{0.910} \\
\hline \multirow{3}{*}{$b l a_{N D M}$} & Absent & 94 & 3 & 94 & 3 & 82 & 15 & 97 & 0 & 97 & 96 & 1 \\
\hline & Present & 12 & 0 & 11 & 1 & 12 & 0 & 11 & 1 & 12 & 11 & 1 \\
\hline & $p$ Value & \multicolumn{2}{|c|}{0.702} & \multicolumn{2}{|c|}{0.377} & \multicolumn{2}{|c|}{0.152} & \multicolumn{2}{|c|}{0.110} & NA & \multicolumn{2}{|c|}{0.209} \\
\hline \multirow{3}{*}{$b l a_{V I M}$} & Absent & 32 & 2 & 34 & 0 & 33 & 1 & 34 & 0 & 34 & 32 & 2 \\
\hline & Present & 74 & 1 & 71 & 4 & 61 & 14 & 74 & 1 & 75 & 75 & 0 \\
\hline & $p$ Value & \multicolumn{2}{|c|}{0.229} & \multicolumn{2}{|c|}{0.218} & \multicolumn{2}{|c|}{0.021} & \multicolumn{2}{|c|}{0.688} & NA & \multicolumn{2}{|c|}{0.095} \\
\hline \multirow{3}{*}{$b a_{T E M}$} & Absent & 58 & 1 & 59 & 0 & 54 & 5 & 59 & 0 & 59 & 59 & 0 \\
\hline & Present & 48 & 2 & 46 & 4 & 40 & 10 & 49 & 1 & 50 & 48 & 2 \\
\hline & $p$ Value & \multicolumn{2}{|c|}{0438} & \multicolumn{2}{|c|}{0.041} & \multicolumn{2}{|c|}{0.072} & \multicolumn{2}{|c|}{0.459} & NA & \multicolumn{2}{|c|}{0.208} \\
\hline \multirow{3}{*}{$b l a_{S H V}$} & Absent & 105 & 3 & 104 & 4 & 93 & 15 & 107 & 1 & 108 & 106 & 2 \\
\hline & Present & 1 & 0 & 1 & 0 & 1 & 0 & 1 & 0 & 1 & 1 & 0 \\
\hline & $p$ Value & \multicolumn{2}{|c|}{0.972} & & & & & & & NA & & \\
\hline & Absent & 53 & 1 & 51 & 3 & 48 & 6 & 54 & 0 & 54 & 52 & 2 \\
\hline$b^{b l a_{C T X}}$ & Present & 53 & 2 & 54 & 1 & 46 & 9 & 54 & 1 & 55 & 55 & 0 \\
\hline & $p$ Value & & & & & & & & & NA & & \\
\hline
\end{tabular}

NA: $p$ Value could not be computed. 


\subsection{Plasmid Profiling}

Among the 109 isolates, 58 (53.2\%) had one or more plasmid (Table 6). Plasmid size estimates ranged from 1.0 to $8.0 \mathrm{kbp}$. The plasmid profile of each of the isolates was distinct as none of the isolates shared similar numbers or sizes of plasmids (Appendix C). No significant associations were observed between number of plasmids and number of resistance genes (Table 6), or between number of plasmids and the resistance to antimicrobial agent groups (Table 7).

Table 6. Association between the number of resistance genes and number of plasmids among the isolates.

\begin{tabular}{|c|c|c|c|c|c|c|c|c|c|}
\hline \multirow{2}{*}{ Number of Resistance Genes } & \multicolumn{7}{|c|}{ Number of Plasmids } & \multirow{2}{*}{ Total } & \multirow{2}{*}{$p$ Value } \\
\hline & $\mathbf{0}$ & 1 & 2 & 3 & 4 & 5 & 6 & & \\
\hline 0 & 6 & 2 & 2 & 0 & 0 & 0 & 1 & 11 & \multirow{6}{*}{0.461} \\
\hline 1 & 11 & 11 & 3 & 0 & 2 & 1 & 0 & 28 & \\
\hline 2 & 23 & 13 & 3 & 1 & 1 & 3 & 0 & 44 & \\
\hline 3 & 9 & 5 & 4 & 3 & 2 & 0 & 0 & 23 & \\
\hline 4 & 1 & 0 & 1 & 0 & 0 & 0 & 0 & 2 & \\
\hline 5 & 1 & 0 & 0 & 0 & 0 & 0 & 0 & 1 & \\
\hline Total (\%) & $\begin{array}{c}51 \\
(46.8)\end{array}$ & $\begin{array}{c}31 \\
(28.4)\end{array}$ & $\begin{array}{c}13 \\
(11.9)\end{array}$ & $\begin{array}{c}4 \\
(3.7)\end{array}$ & $\begin{array}{c}5 \\
(4.6)\end{array}$ & $\begin{array}{c}4 \\
(3.7)\end{array}$ & $\begin{array}{c}1 \\
(0.9)\end{array}$ & $\begin{array}{c}109 \\
(100)\end{array}$ & - \\
\hline
\end{tabular}

Table 7. Association between resistance to antimicrobial agent groups and number of plasmids among the isolates.

\begin{tabular}{ccccccccccc}
\hline \multirow{2}{*}{$\begin{array}{c}\text { Resistance to Antimicrobial } \\
\text { Agent Groups }\end{array}$} & $\mathbf{9}$ & $\mathbf{1}$ & $\mathbf{2}$ & $\mathbf{3}$ & $\mathbf{4}$ & $\mathbf{5}$ & $\mathbf{6}$ & \multirow{2}{*}{ Total } & $\boldsymbol{p}$ Value \\
\cline { 2 - 9 } & 1 & 0 & 0 & 0 & 0 & 1 & 0 & 2 & \\
\hline 0 & 37 & 17 & 3 & 2 & 3 & 1 & 1 & 64 & \\
1 & 9 & 6 & 7 & 2 & 2 & 1 & 0 & 27 & 0.176 \\
2 & 2 & 4 & 2 & 0 & 0 & 1 & 0 & 9 & \\
3 & 2 & 2 & 0 & 0 & 0 & 0 & 0 & 4 & 3 \\
4 & 0 & 2 & 1 & 0 & 0 & 0 & 0 & \\
5 & 51 & 31 & 13 & 4 & 5 & 4 & 1 & 109 & - \\
\hline
\end{tabular}

\section{Discussion}

E. coli is a biological indicator of fecal contamination of water sources. It is a well-known potential pathogen responsible for a variety of waterborne infections in humans, such as gastrointestinal illness. Furthermore, the presence of antimicrobial resistant pathogenic E. coli strains in water sources may contribute to the spreading of antimicrobial resistance and virulence genes among other bacteria in the environment. In this study, E. coli was recovered from various drinking water sources in Jordan. All isolates were subjected to PCR detection of virulence genes associated with E. coli intestinal pathotypes, plasmid profiling, and phenotypic and genotypic analysis of antimicrobial resistance.

Using PCR to detect virulence genes, $22.0 \%$ of the isolates were identified as potentially IPEC. Hence, E. coli obtained from water sources can potentially lead to serious disease. The most prevalent potential pathotype was EAEC accounting for $16.5 \%$ of the isolates, followed by EPEC at $2.8 \%$, EIEC at $1.8 \%$ and putatively EHEC at $0.9 \%$. The one isolate identified putatively as EHEC, was not positive for eae, as is typical for this pathotype. This may be attributed to mutations in the gene preventing PCR amplification. Alternatively, this could be a non-EHEC strain that acquired stx1 via horizontal gene transfer. Isolates demonstrated highest resistance rates against ampicillin and sulfamethoxazole/trimethoprim. All isolates were sensitive to imipenem, meropenem, doripenem and tigecycline. Many agents also demonstrated high susceptibility. Nonetheless, approximately one third of the isolates had an MDR phenotype. 
According to the DDST, $54.1 \%$ of the isolates were ESBL producers. Various types of antimicrobials were used for the phenotypic detection of ESBL producers to enhance detection sensitivity. Ceftizoxime and cefotaxime identified the highest number of ESBL isolates, while ceftazidime identified the least. The CLSI (2015) recommends using multiple agents, including aztreonam, cefotaxime and ceftizoxime for ESBL screening, which is consistent with our methodology and findings. All ESBL positive isolates were susceptible to nitrofurantoin, tigecycline, imipenem, meropenem, and doripenem. Similar results have been reported for E. coli in Iran, South Africa, and Bangladesh [16,19-21]. The observed high rates of MDR are likely due to the dissemination of resistance genes via horizontal gene transfer among bacteria and the relative ease for E. coli to acquire genetic material, especially in light of increased selective pressure due to exposure to a wide range of antimicrobials in the human body, as well as in the environment.

A study from Jordan in 2012 on clinical E. coli isolates reported an ESBL rate of 50.3\%; (83/165) [22]. A rate surprisingly similar to what we found, suggesting that $E$. coli obtained from the drinking water sources are potentially a subset of those involved in clinical infections. For comparison, $55.6 \%$ of clinical E. coli isolates from India were ESBL positive [23], while lower rates of ESBL producing clinical E. coli were reported in Qatar (34.7\%), Iran (21\%), Oman (13.3\%), and Korea (9.2\%) [24-27]. The higher prevalence of ESBL isolates in Jordan compared to other countries may be attributed to the trend of self-medication, unregulated prescription of antimicrobial agents, and the extensive prophylactic misuse of antimicrobials by Jordanian patients and physicians.

While the CLSI (2015) only recommends using ertapenem and meropenem for carbapenemase screening, this study utilized four carbapenem drugs for screening of carbapenemases using the MHT. Based on this, three $(2.8 \%)$ isolates were identified as carbapenemase producers. Carbapenemase positive isolates were only identified using ertapenem and imipenem. Surprisingly, these isolates were still susceptible to all four carbapenem drugs. This could be attributed to the production of low carbapenemase levels, or a false positive MHT mostly generated by ESBL production in association with decreased drug permeability [28]. For comparison, in Lebanon the reported prevalence rate of carbapenemase production was $2.2 \%$ among clinical E. coli isolates [29]. MDR E. coli harboring ESBLs and carbapenemases in water sources is alarming, especially considering that carbapenems are usually the antimicrobials of last resort to treat ESBL-producing pathogens.

Different beta-lactamase genes were detected among the isolates; namely, bla $a_{V I M}(68.8 \%)$ followed by $b l a_{C T X}(50.5 \%), b l a_{T E M}(45.9 \%), b l a_{N D M}(11 \%), b l a_{K P C}(4.6 \%)$, and $b l a_{S H V}(0.9 \%)$. Bla $a_{V I M}$ was the most prevalent gene. This may be due to its presence on highly mobile genetic elements that facilitate its spread among bacteria and that it is the most common ESBL gene distributed worldwide [30]. The presence of $b l a_{V I M}$ in Jordan was documented previously in clinical isolates [31].

The presence of ESBL-producing E. coli possessing $b l a_{\text {СTX }}$ genes in the environment was documented in different parts of the world $[17,32,33]$. Salah et al. reported a very high rate of $94.2 \%$ of E. coli producing CTX-M-type ESBLs in the intestines of Jordanian infants [34]. The high rate of E. coli harboring CTX-M-type ESBLs reported here is consistent with its high prevalence among the intestinal flora reported by Salah et al. and may be attributed to improper clinical waste management leading to contamination of water sources. Consistent with the findings of our study, $50 \%$ of the isolates from water sources in Bangladesh harbored $b l a_{\text {CTX }}$ [21]. The frequency of $b l a_{T E M}$ among the isolates was similar to those reported from Qatar and Malaysia among water isolates $[18,24]$.

Significant associations were observed between $s t x 1$ and $b l a_{K P C}$, aaic and $b l a_{T E M}$, and aat with $b l a_{V I M}$. However, only one $s t x 1$ positive isolate carried $b l a_{K P C}$. Therefore, this association may not be necessarily typical. The co-presence of virulence genes and resistant genes in pathogenic strains likely favors their survival and persistence in the host and the environment [35]. Similarly, the co-presence of $b l a_{C T X}$ and stx 1 was described in E. coli isolates from Japan and France [36,37]. A study from Iran also reported the presence of $b l a_{C T X}$ and bla $a_{T E M}$ in EAEC [38].

Significant co-association was observed between $b l a_{K P C}$ and $b l a_{T E M}$, which may reflect co-existence of the genes, their dissemination on mobile genetic elements via horizontal gene transfer, and the 
ability of bacteria to acquire several resistance genes. Similarly, the co-association of $b l a_{K P C}$ and bla $a_{T E M}$ was reported in E. coli clinical isolates from Taiwan and Greece [39,40].

In the present study, about half of the isolates carried one or more plasmid. This was similar to findings of a study from India in which $52.6 \%$ of E. coli isolates carried plasmids [41]. Plasmid size estimates ranged from 1.0 to $8.0 \mathrm{kbp}$. These findings are in agreement with studies from Bangladesh and Pakistan [42,43].

No significant associations were observed between the number of plasmids and number of resistance genes, suggesting that resistance genes might have translocated from plasmids to the chromosome, and/or that they were carried on a limited number of plasmids. Furthermore, there were no significant associations between resistance to various antimicrobial agent groups and number of plasmids. This may be due to the presence of genes encoding antibiotics resistance on plasmids as well as the bacterial chromosome. Similarly, some strains containing more than one plasmid were reported to be only resistant to one antimicrobial agent, and vice versa [44]. Other studies also reported no correlation between the number of plasmids and resistance patterns [45].

Due to the identification of potentially IPEC having high rates of drug resistance among drinking water sources, we suggest implementation of wider-scale studies to characterize their presence and the presence of other potential pathogens, and the identification of isolates' virulence and antimicrobial resistance determinants. Furthermore, periodical monitoring of E. coli and other pathogens among water sources is required to assess their contribution to waterborne infections and health of the population, and to evaluate if water sources may serve as reservoirs for these pathogens.

\section{Materials and Methods}

This study was approved by the Jordan University of Science and Technology (JUST) research committee. Requirement for approval by the institutional review board of JUST was waived as the study did not involve the study of human subjects, human data or tissue, or animals.

\subsection{Bacterial Isolates}

A total of 157 suspected Escherichia coli isolates were obtained from the water testing authority's microbiology laboratory, Amman, Jordan from February to June 2015. Water samples processed at this laboratory originated from all sources of the drinking water supply in Jordan. Isolates were obtained from fluorescent wells of a Colilert Quanti-Tray (IDEXX Laboratories, Westbrook, ME, USA) and streaked onto MacConkey agar, followed by subculture on eosin-methylene blue agar. The identity of all isolates was confirmed using conventional methods, and PCR via detection of the E. coli-specific gene uspA. Of the total 157 isolates, 109 were confirmed as E. coli. For long term storage, overnight colonies from agar media were suspended in LB broth supplemented with glycerol (16\% final concentration), and stored at $-80^{\circ} \mathrm{C}$. Bacterial colonies from overnight cultures on Muller Hinton agar (MHA) were resuspended in $2.0 \mathrm{~mL}$ of sterile normal saline, to create a bacterial suspension having a turbidity equivalent to $0.5 \mathrm{McF}$ arland for antimicrobial susceptibility testing (AST).

\subsection{Antimicrobial Susceptibility Testing}

AST was performed using the Kirby-Bauer disk diffusion method according to the Clinical and Laboratory Standards Institute (CLSI, 2015) guidelines. Any isolate showing a resistant or intermediately susceptible result using the Kirby-Bauer disk diffusion method was considered nonsusceptible to the respective antimicrobial agent. The antimicrobial disks used were amoxicillin/clavulanic acid $(30 \mu \mathrm{g})$, aztreonam $(30 \mu \mathrm{g})$, cefotaxime $(30 \mu \mathrm{g})$, ceftazidime $(30 \mu \mathrm{g})$, ceftizoxime $(30 \mu \mathrm{g})$, ceftriaxone $(30 \mu \mathrm{g})$, ampicillin $(10 \mu \mathrm{g})$, ciprofloxacin $(5 \mu \mathrm{g})$, levofloxacin $(5 \mu \mathrm{g})$, nitrofurantoin $(300 \mu \mathrm{g})$, sulfamethoxazole-trimethoprim $(25 \mu \mathrm{g})$, tigecycline $(15 \mu \mathrm{g})$, doripenem $(10 \mu \mathrm{g})$, ertapenem $(10 \mu \mathrm{g})$, imipenem $(10 \mu \mathrm{g})$, and meropenem $(10 \mu \mathrm{g})$. All disks were obtained from Oxoid (Basingstoke, Hampshire UK). E. coli clinical isolates having known AST profiles as determined by VITEK (bioMérieux, Marcy-l'Étoile, France) were used as positive and negative controls. 


\subsection{Detection of ESBLS}

The production of ESBLs was detected by the double disk synergy test (DDST) according to the CLSI (2015) guidelines using a disk of amoxicillin/clavulanic acid along with aztreonam, cefotaxime, ceftazidime, ceftizoxime, and ceftriaxone. An MHA plate was inoculated with each isolate. Next, an amoxicillin/clavulanic acid disk was placed in the center of the plate, and aztreonam, cefotaxime, ceftazidime, ceftizoxime, ceftriaxone disks were placed $25 \mathrm{~mm}$ (center to center) from the amoxicillin/clavulanic acid disk. After overnight incubation at $37^{\circ} \mathrm{C}$, any distortion or increase in the zone of inhibition (i.e., augmentation of inhibition) towards the amoxicillin/clavulanic acid disk was considered a positive result for ESBL production. Klebsiella pneumoniae ATCC 700603 was used as positive control. E. coli ATCC 25922 was used as negative control.

\subsection{Detection of Carbapenemase Production}

Carbapenemase production was evaluated using the Modified Hodge test (MHT) according to the CLSI (2015) guidelines. Briefly, a 0.5 McFarland-equivalent suspension of E. coli ATCC 25922 in $5 \mathrm{~mL}$ of sterile saline was prepared. A 1:10 dilution was prepared in sterile saline. The diluted suspension was used to inoculate the full surface of an MHA plate. The plate was dried for $5 \mathrm{~min}$ and a disk of either doripenem $(10 \mu \mathrm{g})$, ertapenem $(10 \mu \mathrm{g})$, imipenem $(10 \mu \mathrm{g})$, or meropenem $(10 \mu \mathrm{g})$, was placed in the center of the plate. Two-to-four colonies of the test organism were selected and streaked in a straight line, from the edge of the disk, up to the edge of the plate. After overnight incubation at $36^{\circ} \mathrm{C}$, carbapenemase production was identified by observing a clover leaf-like indentation of $E$. coli ATCC 25922 growing along the test organism's growth streak within the disk diffusion zone [46]. K. pneumoniae ATCC BAA-1705 was used as a positive control. K. pneumoniae ATCC BAA-1706 was used as a negative control.

\subsection{Plasmid Profiling}

Plasmid DNA was extracted from all isolates by the alkaline lysis method using the Zyppy ${ }^{\mathrm{TM}}$ Plasmid Miniprep Kit (Zymo Research, Irvine, CA, USA) according to the manufacturer instructions. Seven microliters of each plasmid DNA sample were mixed with $1.5 \mu \mathrm{L}$ of loading dye (6X), and the mixture was loaded on $0.7 \%$ agarose. GeneRuler ${ }^{\mathrm{TM}}$ one kilo-base DNA linear Ladder (Fisher Scientific, Loughborough, UK) was used as a reference marker. Samples were electrophoresed for one hour at $150 \mathrm{~V}$ in a $1 \mathrm{X}$ Tris-borate- EDTA buffer, and the gel was photographed using a UV transilluminator. No restriction enzymes were utilized before electrophoretic separation. Hence, plasmid sizes measured were estimates based on the size of supercoiled plasmid DNA. A clinical isolate of $E$. coli previously identified to possess plasmids was used as a positive control. A clinical isolate previously identified to have no plasmids was used as a negative control.

\subsection{Total DNA Extraction}

Total genomic (chromosomal and plasmid) DNA was extracted from the isolates using a simple boiling method. Briefly, two pure bacterial colonies were inoculated into $5 \mathrm{~mL}$ of LB broth and the tubes were incubated overnight at $37^{\circ} \mathrm{C}$ for $16 \mathrm{~h}$. Next, $1.5 \mathrm{~mL}$ of overnight culture was transferred to an Eppendorf tube and centrifuged at $13,000 \times \mathrm{g}$ for $10 \mathrm{~min}$. The bacterial pellet was suspended in $300 \mu \mathrm{L}$ sterile water and heated at $100{ }^{\circ} \mathrm{C}$ for $10 \mathrm{~min}$ to lyse the cells. Debris were removed by centrifugation at $13,000 \times g$ for $10 \mathrm{~min}$ and the supernatant was transferred into an Eppendorf tube. The extracted DNA was stored at $-20^{\circ} \mathrm{C}$ until used for PCR.

\subsection{PCR for Isolates' Identification and Detection of Resistance Genes}

PCR was performed to confirm the identity of the 157 isolates by detecting the E. coli-specific $u s p A$, as described previously [47]. The $25 \mu \mathrm{L}$ PCR contained $12.5 \mu \mathrm{L} 2 \mathrm{X}$ PCR master mix solution, $2 \mu \mathrm{L}$ template bacteria DNA solution, $1.5 \mu \mathrm{L}$ of both forward and reverse primers for each of the 
targeted genes $(6.25$ pmoles $/ \mu \mathrm{L})$ and $7.5 \mu \mathrm{L}$ nuclease free water. The following PCR conditions were used; $5 \mathrm{~min}$ at $94{ }^{\circ} \mathrm{C}$, followed by 30 cycles of $94{ }^{\circ} \mathrm{C}$ for $2 \mathrm{~min}, 70{ }^{\circ} \mathrm{C}$ for $1 \mathrm{~min}$, and $72{ }^{\circ} \mathrm{C}$ for $1 \mathrm{~min}$. The 109 isolates confirmed as E. coli (uspA positive) underwent PCR for detection of virulence and resistance genes. Multiplex PCR was performed to detect eae of EPEC, in addition to aaiC and aat of EAEC, as described previously [19]. Three pairs of primers, were used for amplification of these genes. The $25 \mu \mathrm{L}$ PCR contained $12.5 \mu \mathrm{L} 2$ X PCR master mix solution, $3 \mu \mathrm{L}$ template bacteria DNA solution, $0.4 \mu \mathrm{L}$ of both forward and reverse primers $(6.25$ pmoles $/ \mu \mathrm{L})$ for each of aaiC and aat, $0.44 \mu \mathrm{L}$ of both forward and reverse primers $(6.25 \mathrm{pmoles} / \mu \mathrm{L})$ for eae, and $7.02 \mu \mathrm{L}$ nuclease free water. The following PCR conditions were used; $4 \mathrm{~min}$ at $96{ }^{\circ} \mathrm{C}$, followed by 34 cycles of $95{ }^{\circ} \mathrm{C}$ for $20 \mathrm{~s}, 57{ }^{\circ} \mathrm{C}$ for $20 \mathrm{~s}$, and $72{ }^{\circ} \mathrm{C}$ for $1 \mathrm{~min}$. Touchdown multiplex PCR was performed to detect st $x 1$ and st $x 2$ of EHEC as described previously $[19,48]$. The $25 \mu \mathrm{L}$ PCR contained $12.5 \mu \mathrm{L} 2$ X PCR master mix solution, $3 \mu \mathrm{L}$ template bacteria DNA solution, $0.5 \mu \mathrm{L}$ of both forward and reverse primers $(6.25 \mathrm{pmoles} / \mu \mathrm{L})$ of each targeted gene, and $7.5 \mu \mathrm{L}$ nuclease free water. The following PCR conditions were used; $94{ }^{\circ} \mathrm{C}$ for $5 \mathrm{~min}$, followed by 40 -cycle each of $94{ }^{\circ} \mathrm{C}$ for $30 \mathrm{~s}, 64{ }^{\circ} \mathrm{C}$ for $30 \mathrm{~s}$, and $72{ }^{\circ} \mathrm{C}$ for $60 \mathrm{~s}$, for two cycles followed by eight cycles having a $2{ }^{\circ} \mathrm{C}$ decrease of annealing temperature after every two cycles. When the annealing temperature of $54{ }^{\circ} \mathrm{C}$ was reached at cycle 10 , the PCR continued with these cycling parameters followed by a final extension at $72{ }^{\circ} \mathrm{C}$ for $10 \mathrm{~min}$. PCR was performed to detect ipaH of EIEC as described previously [19]. The $25 \mu \mathrm{L}$ PCR contained $12.5 \mu \mathrm{L} 2 \mathrm{X}$ PCR master mix solution, $2 \mu \mathrm{L}$ template bacteria DNA solution, $2 \mu \mathrm{L}$ of both forward and reverse primers for the $i p a H$ gene $(6.25$ pmoles $/ \mu \mathrm{L})$, and $6.5 \mu \mathrm{L}$ nuclease free water. The following PCR conditions were used $95^{\circ} \mathrm{C}$ for $5 \mathrm{~min}, 30$ cycles of $95^{\circ} \mathrm{C}$ for $50 \mathrm{~s}, 55^{\circ} \mathrm{C}$ for $1.5 \mathrm{~min}$, and $72{ }^{\circ} \mathrm{C}$ for $2 \mathrm{~min}$, with a final extension at $72{ }^{\circ} \mathrm{C}$ for $7 \mathrm{~min}$. Table 8 lists PCR primers used.

Table 8. Primers used for PCR.

\begin{tabular}{|c|c|c|c|c|c|}
\hline Gene & Primer & Primer Sequence $\left(5^{\prime}-3^{\prime}\right)$ & $\begin{array}{c}\text { Annealing } \\
\text { Temperature } \\
\left({ }^{\circ} \mathrm{C}\right)\end{array}$ & $\begin{array}{c}\text { PCR } \\
\text { Product } \\
\text { Size (bp) }\end{array}$ & Reference \\
\hline \multirow[t]{2}{*}{ uspA } & uspA-F & CCGATACGCTGCCAATCAGT & 64 & 884 & [47] \\
\hline & uspA-R & ACGCAGACCGTAGGCCAGAT & & & \\
\hline \multirow[t]{2}{*}{ eae } & eae-F & CCCGAATTCGGCACAAGCATAAGC & 57 & 881 & [19] \\
\hline & eae-R & CCCGGATCCGTCTCGCCAGTATTCG & & & \\
\hline \multirow[t]{2}{*}{ aaic } & aaiC-F & ATTGTCCTCAGGCATTTCAC & 57 & 215 & [19] \\
\hline & aaiC-R & ACGACACCCCTGATAAACAA & & & \\
\hline \multirow[t]{2}{*}{ aat } & aat-F & CTGGCGAAAGACTGTATCAT & 57 & 650 & [19] \\
\hline & aat-R & CAATGTATAGAAATCCGCTGTT & & & \\
\hline \multirow[t]{2}{*}{ stx 1} & stx $1-\mathrm{F}$ & CACAATCAGGCGTCGCCAGCGCACTTGCT & $64 *$ & 606 & [19] \\
\hline & stxi-R & TGTTGCAGGGATCAGTGGTACGGGGATGC & & & \\
\hline \multirow[t]{2}{*}{ stx 2} & stx2-F & CCACATCGGTGTCTGTTATTAACCACACC & $64 *$ & 372 & [19] \\
\hline & stx $2-\mathrm{R}$ & GCAGAACTGCTCTGGATGCATCTCTGGTC & & & \\
\hline \multirow[t]{2}{*}{$i p a H$} & Shig-F & TGGAAAAACTCAGTGCCTCT & 55 & 424 & [19] \\
\hline & Shig-R & CCAGTCCGTAAATTCATTCT & & & \\
\hline \multirow[t]{2}{*}{$b l a_{K P C}$} & KPC-Fm & CGTCTAGTTCTGCTGTCTTG & 52 & 798 & [49] \\
\hline & KPC-Rm & CTTGTCATCCTTGTTAGGCG & & & \\
\hline \multirow{2}{*}{$b l a_{N D M}$} & NDM-F & GGTTTGGCGATCTGGTTTTC & 52 & 621 & [49] \\
\hline & NDM-R & CGGAATGGCTCATCACGATC & & & \\
\hline \multirow[t]{2}{*}{$b l a_{V I M}$} & VIM-F & GATGGTGTTTGGTCGCATA & 52 & 390 & [49] \\
\hline & VIM-R & CGAATGCGCAGCACCAG & & & \\
\hline \multirow[t]{2}{*}{$b l a_{T E M}$} & TEM-F & ACATGGGGGATCATGTAACT & 52 & 421 & {$[50]$} \\
\hline & TEM-R & GACAGTTACAATGCTTACT & & & \\
\hline \multirow[t]{2}{*}{$b l a_{S H V}$} & SHV-F & ATGCGTTATATTCGCCTGTG & 56 & 859 & [50] \\
\hline & SHV-R & AGCGTTGCCAGTGCTCGATG & & & \\
\hline \multirow[t]{2}{*}{$b l a_{C T X}$} & CTX-MU1 & ATGTGCAGYACCAGTAARGT & 50 & 593 & [50] \\
\hline & CTX-MU2 & TGGGTRAARTARGTSACCAGT & & & \\
\hline
\end{tabular}

Notes: * PCR involved 40 cycles having initial annealing at $64{ }^{\circ} \mathrm{C}$ for two cycles followed by eight cycles having a

$2{ }^{\circ} \mathrm{C}$ decrease in annealing temperature after every two cycles. 
Multiplex PCR assay was performed to detect carbapenem resistance genes $\left(b l a_{K P C}, b l a_{N D M}\right.$, and bla $\left._{V I M}\right)$, as described previously [49]. The $25 \mu \mathrm{L}$ PCR contained $12.5 \mu \mathrm{L} 2 \mathrm{X}$ PCR master mix solution, $1 \mu \mathrm{L}$ template bacteria DNA solution, $0.75 \mu \mathrm{L}$ of both forward and reverse primers $(6.25 \mathrm{pmoles} / \mu \mathrm{L})$ for each of the targeted genes, and seven $\mu \mathrm{L}$ nuclease free water. The following PCR conditions were used; $10 \mathrm{~min}$ at $94^{\circ} \mathrm{C} ; 36$ cycles of $30 \mathrm{~s}$ at $94{ }^{\circ} \mathrm{C}, 40 \mathrm{~s}$ at $52^{\circ} \mathrm{C}$, and $50 \mathrm{~s}$ at $72{ }^{\circ} \mathrm{C}$, and final extension at $72{ }^{\circ} \mathrm{C}$ for $5 \mathrm{~min}$. PCR was performed to detect ESBL genes (bla $a_{C T X}, b l a_{T E M}$, and $b l a_{S H V}$ ), as described previously [50]. The $25 \mu \mathrm{L}$ PCR contained $12.5 \mu \mathrm{L} 2$ X PCR master mix solution, $3 \mu \mathrm{L}$ template bacteria DNA solution, $0.83 \mu \mathrm{L}$ of both forward and reverse primers $(6.25 \mathrm{pmoles} / \mu \mathrm{L})$ of each targeted gene, and $7.84 \mu \mathrm{L}$ nuclease free water. The following PCR conditions were used; $5 \mathrm{~min}$ at $94{ }^{\circ} \mathrm{C}$, followed by 35 cycles of $30 \mathrm{~s}$ at $94{ }^{\circ} \mathrm{C}$ denaturation, $30 \mathrm{~s}$ at $\left(50{ }^{\circ} \mathrm{C}\right.$ for $b l a_{C T X}, 52^{\circ} \mathrm{C}$ for $b l a_{T E M}$, and $56^{\circ} \mathrm{C}$ for $\left.b l a_{S H V}\right)$ for annealing, $30 \mathrm{~s}\left(60 \mathrm{~s}\right.$ for $\left.b l a_{S H V}\right)$ at $72{ }^{\circ} \mathrm{C}$ for extension, and a final elongation step of $5 \mathrm{~min}$ at $72{ }^{\circ} \mathrm{C}$. Controls for PCR were K. pneumoniae ATCC BAA-1706 (bla $a_{\mathrm{KPC}}$ and bla $a_{\mathrm{NDM}}$ negative control), K. pneumoniae ATCC BAA-1705 (bla $a_{\mathrm{KPC}}$ positive control), K. pneumoniae ATCC BAA-2146 (bla $a_{\mathrm{NDM}}$ positive control), K. pneumoniae ATCC 700603 (bla $a_{\mathrm{SHV}}$ positive control), and E. coli ATCC 35218 (bla TEM $_{\mathrm{TEM}}$ positive control). Amplification products were detected by electrophoretic separation on $1.5 \%$ agarose. For genes having no positive control strains, representative PCR bands were sequenced for verification of amplified genes. Table 8 lists PCR primers used.

\subsection{Statistical Analysis}

The SPSS software version 21 (IBM, Armonk, NY, USA) was used to generate the descriptive analysis of raw data, including generation of all frequency tables and cross tabulations. Fisher's exact test was used to compare frequency data. Associations between plasmid profiles with resistance genes and phenotypes were investigated using Pearson's Chi-square test. A $p$ value equal to or less than 0.05 was considered statistically significant. Full study data are available online as supplementary material (Table S1).

\section{Conclusions}

In conclusion, $22 \%$ of the E. coli isolates recovered from drinking water sources in Jordan were potentially intestinal pathogenic strains, most likely being EAEC. Many isolates harbored beta-lactamase resistance genes, had an MDR phenotype, and an ESBL phenotype. Carbapenemase production was infrequent. None of the isolates had similar plasmid profiles.

Supplementary Materials: The following are available online at http://www.mdpi.com/2076-0817/8/2/86/s1, Table S1: Full data sets in Microsoft Excel file format.

Author Contributions: Conceptualization, S.S. and H.A.; Methodology, S.S.; Validation, S.S.; Formal analysis, S.S. and H.A.; Investigation, S.S. and H.A.; Resources, S.S.; Data curation, S.S.; Writing-original draft preparation, S.S. and H.A.; Writing—-review and editing, S.S. and H.A.; Visualization, S.S.; Supervision, S.S.; Project administration, S.S.; Funding acquisition, S.S.

Funding: This research was funded by the Deanship of research of Jordan University of Science and Technology, grant number 20150078 and the APC was partly covered by Jordan University of Science and Technology.

Acknowledgments: We thank the Princess Haya biotechnology center for their valuable support.

Conflicts of Interest: The authors declare no conflict of interest. 


\section{Appendix A}

Table A1. Correlation between ESBL phenotype and antimicrobial susceptibility.

\begin{tabular}{|c|c|c|c|c|}
\hline & & \multicolumn{2}{|c|}{ ESBL Producer } & \multirow{3}{*}{$p$ Value } \\
\hline \multicolumn{2}{|c|}{ Antimicrobial Agent } & \multirow{2}{*}{$\begin{array}{c}\text { No } \\
\text { Number (\%) }\end{array}$} & \multirow{2}{*}{$\begin{array}{c}\text { Yes } \\
\text { Number (\%) }\end{array}$} & \\
\hline & & & & \\
\hline \multirow{2}{*}{ AMC } & Not susceptible & $9(18)$ & $20(33.9)$ & \multirow{2}{*}{0.048} \\
\hline & Susceptible & $41(82)$ & $39(66.1)$ & \\
\hline \multirow{2}{*}{ ATM } & Not susceptible & $1(2)$ & $11(18.6)$ & \multirow{2}{*}{0.005} \\
\hline & Susceptible & $49(98)$ & $48(81.4)$ & \\
\hline \multirow{2}{*}{ CTX } & Not susceptible & $1(2)$ & $14(23.7)$ & \multirow{2}{*}{0.001} \\
\hline & Susceptible & $49(98)$ & $45(76.3)$ & \\
\hline \multirow{2}{*}{ CAZ } & Not susceptible & $2(4)$ & $9(15.3)$ & \multirow{2}{*}{0.049} \\
\hline & Susceptible & $48(96)$ & $50(84.7)$ & \\
\hline \multirow{2}{*}{ ZOX } & Not susceptible & $1(2)$ & $11(18.6)$ & \multirow{2}{*}{0.005} \\
\hline & Susceptible & $49(98)$ & $48(81.4)$ & \\
\hline \multirow{2}{*}{ CRO } & Not susceptible & $1(2)$ & $14(23.7)$ & \multirow{2}{*}{0.001} \\
\hline & Susceptible & $49(98)$ & $45(76.3)$ & \\
\hline \multirow{2}{*}{$\mathrm{AM}$} & Not susceptible & $47(94)$ & $59(100)$ & \multirow{2}{*}{0.093} \\
\hline & Susceptible & $3(6)$ & - & \\
\hline \multirow{2}{*}{$\mathrm{CIP}$} & Not susceptible & $10(20)$ & $8(13.6)$ & \multirow{2}{*}{0.259} \\
\hline & Susceptible & $40(80)$ & $51(86.4)$ & \\
\hline \multirow{2}{*}{ LEV } & Not susceptible & $10(20)$ & $7(11.9)$ & \multirow{2}{*}{0.184} \\
\hline & Susceptible & $40(80)$ & $52(88.1)$ & \\
\hline \multirow{2}{*}{$\mathrm{F}$} & Not susceptible & $2(4)$ & - & \multirow{2}{*}{0.208} \\
\hline & Susceptible & $48(96)$ & $59(100)$ & \\
\hline \multirow{2}{*}{ SXT } & Not susceptible & $19(38)$ & $27(45.8)$ & \multirow{2}{*}{0.267} \\
\hline & Susceptible & $31(62)$ & $32(54.2)$ & \\
\hline TGC & Susceptible & $50(100)$ & $59(100)$ & NA \\
\hline DOR & Susceptible & $50(100)$ & $59(100)$ & NA \\
\hline \multirow{2}{*}{ ETP } & Not susceptible & $2(4)$ & $3(5.1)$ & \multirow{2}{*}{0.579} \\
\hline & Susceptible & $48(96)$ & $56(94.9)$ & \\
\hline IPM & Susceptible & $50(100)$ & $59(100)$ & NA \\
\hline MEM & Susceptible & $50(100)$ & $59(100)$ & NA \\
\hline
\end{tabular}

Notes: Percentage is calculated within the column of each antimicrobial agent. NA: $p$ value could not be computed. AMC: Amoxicillin/clavulanic acid. ZOX: Ceftizoxime. CAZ: Ceftazidime. CRO: Ceftriaxone. CTX: Cefotaxime. ATM: Aztreonam. AM: Ampicillin. SXT: Sulfamethoxazole/trimethoprim. F: Nitrofurantoin. LEV: Levofloxacin. CIP: Ciprofloxacin. TGC: Tigecycline. IPM: Imipenem. MEM: Meropenem. ETP: Ertapenem. DOR: Doripenem.

\section{Appendix B}

Table A2. Correlation between carbapenemase phenotype and antimicrobial susceptibility.

\begin{tabular}{|c|c|c|c|c|}
\hline \multirow{2}{*}{\multicolumn{2}{|c|}{ Antimicrobial Agent }} & \multicolumn{2}{|c|}{ Carbapenemase Producer } & \multirow{3}{*}{$p$ Value } \\
\hline & & \multirow{2}{*}{$\begin{array}{c}\text { No } \\
\text { Number (\%) }\end{array}$} & \multirow{2}{*}{$\frac{\text { Yes }}{\text { Number (\%) }}$} & \\
\hline & & & & \\
\hline \multirow{2}{*}{$\mathrm{AMC}$} & Not susceptible & $26(24.5)$ & $3(100)$ & \multirow{2}{*}{0.017} \\
\hline & Susceptible & $80(75.5)$ & 0 & \\
\hline \multirow{2}{*}{ ATM } & Not susceptible & $10(9.4)$ & $2(66.7)$ & \multirow{2}{*}{0.032} \\
\hline & Susceptible & $96(90.6)$ & $1(33.3)$ & \\
\hline
\end{tabular}


Table A2. Cont.

\begin{tabular}{|c|c|c|c|c|}
\hline & & \multicolumn{2}{|c|}{ Carbapenemase Producer } & \multirow{3}{*}{$p$ Value } \\
\hline \multicolumn{2}{|c|}{ Antimicrobial Agent } & \multirow{2}{*}{$\begin{array}{c}\text { No } \\
\text { Number (\%) }\end{array}$} & \multirow{2}{*}{$\begin{array}{c}\text { Yes } \\
\text { Number (\%) }\end{array}$} & \\
\hline & & & & \\
\hline \multirow{2}{*}{ CTX } & Not susceptible & $13(12.3)$ & $2(66.7)$ & \multirow{2}{*}{0.049} \\
\hline & Susceptible & $93(87.7)$ & $1(33.3)$ & \\
\hline \multirow{2}{*}{ CAZ } & Not susceptible & $9(8.5)$ & $2(66.7)$ & \multirow{2}{*}{0.026} \\
\hline & Susceptible & $97(91.5)$ & $1(33.3)$ & \\
\hline \multirow{2}{*}{ ZOX } & Not susceptible & $10(9.4)$ & $2(66.7)$ & \multirow{2}{*}{0.032} \\
\hline & Susceptible & $96(90.6)$ & $1(33.3)$ & \\
\hline \multirow{2}{*}{$\mathrm{CRO}$} & Not susceptible & $13(12.3)$ & $2(66.7)$ & \multirow{2}{*}{0.049} \\
\hline & Susceptible & $93(87.7)$ & $1(33.3)$ & \\
\hline \multirow{2}{*}{$\mathrm{AM}$} & Not susceptible & $103(97.2)$ & $3(100)$ & \multirow{2}{*}{0.919} \\
\hline & Susceptible & $3(2.8)$ & 0 & \\
\hline \multirow{2}{*}{$\mathrm{CIP}$} & Not susceptible & $16(15.1)$ & $2(66.7)$ & \multirow{2}{*}{0.070} \\
\hline & Susceptible & $90(84.9)$ & $1(33.3)$ & \\
\hline \multirow{2}{*}{ LEV } & Not susceptible & $15(14.2)$ & $2(66.7)$ & \multirow{2}{*}{0.063} \\
\hline & Susceptible & $91(85.8)$ & $1(33.3)$ & \\
\hline \multirow{2}{*}{$\mathrm{F}$} & Not susceptible & $2(1.9)$ & 0 & \multirow{2}{*}{0.945} \\
\hline & Susceptible & $104(98.1)$ & $3(100)$ & \\
\hline \multirow{2}{*}{ SXT } & Not susceptible & $43(40.6)$ & $3(100)$ & \multirow{2}{*}{0.072} \\
\hline & Susceptible & $63(59.4)$ & 0 & \\
\hline TGC & Susceptible & $106(100)$ & $3(100)$ & NA \\
\hline DOR & Susceptible & $106(100)$ & $3(100)$ & NA \\
\hline \multirow{2}{*}{ ETP } & Not susceptible & $5(4.7)$ & 0 & \multirow{2}{*}{0.867} \\
\hline & Susceptible & $101(95.3)$ & $3(100)$ & \\
\hline IPM & Susceptible & $106(100)$ & $3(100)$ & NA \\
\hline MEM & Susceptible & $106(100)$ & $3(100)$ & NA \\
\hline
\end{tabular}

Notes: Percentage is calculated within the column of each antimicrobial agent. NA: $p$ value could not be computed. AMC: Amoxicillin/clavulanic acid. ZOX: Ceftizoxime. CAZ: Ceftazidime. CRO: Ceftriaxone. CTX: Cefotaxime. ATM: Aztreonam. AM: Ampicillin. SXT: Sulfamethoxazole/trimethoprim. F: Nitrofurantoin. LEV: Levofloxacin. CIP: Ciprofloxacin. TGC: Tigecycline. IPM: Imipenem. MEM: Meropenem. ETP: Ertapenem. DOR: Doripenem.

\section{Appendix C}

Table A3. Isolates' plasmid profiles.

\begin{tabular}{ccc}
\hline Isolate ID & Plasmid Number & Plasmid Size Estimate (bp) \\
\hline 1 & 0 & NA \\
5 & 4 & $4000 \backslash 3000 \backslash 2400 \backslash 1500$ \\
8 & 0 & NA \\
10 & 0 & NA \\
12 & 0 & NA \\
13 & 1 & 3000 \\
15 & 1 & 4000 \\
17 & 0 & NA \\
18 & 1 & 4200 \\
19 & 3 & $7000 \backslash 3200 \backslash 2800$ \\
20 & 3 & $2500 \backslash 1700 \backslash 1000$ \\
21 & 1 & 6000 \\
31 & 6 & 1000 \\
32 & 1 & $8000 \backslash 7000 \backslash 5000 \backslash 3500 \backslash 2550 \backslash 1600$ \\
\hline
\end{tabular}


Table A3. Cont.

\begin{tabular}{|c|c|c|}
\hline Isolate ID & Plasmid Number & Plasmid Size Estimate (bp) \\
\hline 33 & 1 & 3500 \\
\hline 34 & 2 & $6500 \backslash 2000$ \\
\hline 37 & 5 & $4000 \backslash 2500 \backslash 1800 \backslash 1500 \backslash 1100$ \\
\hline 38 & 1 & 5000 \\
\hline 45 & 0 & NA \\
\hline 46 & 0 & NA \\
\hline 48 & 0 & NA \\
\hline 49 & 1 & 4000 \\
\hline 62 & 5 & $6000 \backslash 5000 \backslash 3500 \backslash 1400 \backslash 1250$ \\
\hline 63 & 0 & NA \\
\hline 66 & 0 & NA \\
\hline 68 & 1 & 1300 \\
\hline 70 & 0 & NA \\
\hline 71 & 0 & NA \\
\hline 73 & 0 & NA \\
\hline 77 & 0 & NA \\
\hline 78 & 0 & NA \\
\hline 81 & 5 & $8000 \backslash 4800 \backslash 1900 \backslash 1600 \backslash 1400$ \\
\hline 83 & 0 & NA \\
\hline 86 & 1 & 2800 \\
\hline 87 & 0 & NA \\
\hline 88 & 0 & NA \\
\hline 89 & 0 & NA \\
\hline 90 & 0 & NA \\
\hline 93 & 1 & 3500 \\
\hline 100 & 1 & 3000 \\
\hline 101 & 0 & NA \\
\hline 103 & 0 & NA \\
\hline 104 & 0 & NA \\
\hline 105 & 5 & $8000 \backslash 4000 \backslash 3000 \backslash 1800 \backslash 1500$ \\
\hline 107 & 1 & 1300 \\
\hline 108 & 1 & 3950 \\
\hline 110 & 0 & NA \\
\hline 113 & 1 & 8000 \\
\hline 115 & 1 & 7000 \\
\hline 116 & 0 & NA \\
\hline 117 & 4 & $7000 \backslash 5000 \backslash 3500 \backslash 2400$ \\
\hline 122 & 0 & NA \\
\hline 123 & 0 & NA \\
\hline 124 & 0 & NA \\
\hline 126 & 1 & 1400 \\
\hline 127 & 2 & $2000 \backslash 1800$ \\
\hline 129 & 2 & $6000 \backslash 5000$ \\
\hline 130 & 1 & 6000 \\
\hline 135 & 1 & 2000 \\
\hline 136 & 2 & $4000 \backslash 1300$ \\
\hline 143 & 2 & $3000 \backslash 2400$ \\
\hline 149 & 4 & $4000 \backslash 2000 \backslash 1600 \backslash 1000$ \\
\hline 150 & 3 & $3000 \backslash 2000 \backslash 1990$ \\
\hline 151 & 2 & $1900 \backslash 1500$ \\
\hline 152 & 0 & NA \\
\hline 157 & 0 & NA \\
\hline 158 & 0 & NA \\
\hline 159 & 1 & 1200 \\
\hline 161 & 1 & 3000 \\
\hline 163 & 2 & $2900 \backslash 2100$ \\
\hline 164 & 0 & NA \\
\hline 169 & 0 & NA \\
\hline
\end{tabular}


Table A3. Cont.

\begin{tabular}{|c|c|c|}
\hline Isolate ID & Plasmid Number & Plasmid Size Estimate (bp) \\
\hline 171 & 1 & 3000 \\
\hline 173 & 2 & $8000 \backslash 6000$ \\
\hline 174 & 2 & $5000 \backslash 1500$ \\
\hline 175 & 0 & NA \\
\hline 177 & 4 & $5000 \backslash 4000 \backslash 2500 \backslash 1250$ \\
\hline 179 & 0 & NA \\
\hline 180 & 1 & 2800 \\
\hline 185 & 2 & $6000 \backslash 2400$ \\
\hline 186 & 1 & 3500 \\
\hline 189 & 1 & 2000 \\
\hline 194 & 0 & NA \\
\hline 195 & 1 & 2800 \\
\hline 241 & 0 & NA \\
\hline 242 & 4 & $4800 \backslash 4000 \backslash 3000 \backslash 2600$ \\
\hline 245 & 3 & $6000 \backslash 4600 \backslash 1400$ \\
\hline 246 & 1 & 1800 \\
\hline 247 & 0 & NA \\
\hline 248 & 1 & 2300 \\
\hline 250 & 0 & NA \\
\hline 253 & 0 & NA \\
\hline 255 & 1 & 4000 \\
\hline 260 & 0 & NA \\
\hline 261 & 0 & NA \\
\hline 262 & 0 & NA \\
\hline 263 & 0 & NA \\
\hline 266 & 0 & NA \\
\hline 267 & 0 & NA \\
\hline 268 & 0 & NA \\
\hline 269 & 0 & NA \\
\hline 271 & 2 & $4600 \backslash 3500$ \\
\hline 272 & 0 & NA \\
\hline 274 & 0 & NA \\
\hline 275 & 1 & 1300 \\
\hline 280 & 2 & $8000 \backslash 3500$ \\
\hline 281 & 0 & NA \\
\hline 282 & 2 & $6000 \backslash 4200$ \\
\hline 284 & 1 & 2000 \\
\hline
\end{tabular}

Note: NA: isolate did not carry any plasmid.

\section{References}

1. Ferrer, S.R.; Strina, A.; Jesus, S.R.; Ribeiro, H.C.; Cairncross, S.; Rodrigues, L.C.; Barreto, M.L. A hierarchical model for studying risk factors for childhood diarrhoea: A case-control study in a middle-income country. Int. J. Epidemiol. 2008, 37, 805-815. [CrossRef] [PubMed]

2. UNICEF; WHO. Diarrhoea: Why Children Are Still Dying and What Can Be Done; UNICEF: New York, NY, USA, 2009.

3. Nataro, J.P.; Kaper, J.B. Diarrheagenic Escherichia coli. Clin. Microbiol. Rev. 1998, 11, 142-201. [CrossRef] [PubMed]

4. Cabral, J.P. Water microbiology. Bacterial pathogens and water. Int. J. Environ. Res. Public Health 2010, 7, 3657-3703. [CrossRef] [PubMed]

5. Kaper, J.B.; Nataro, J.P.; Mobley, H.L. Pathogenic Escherichia coli. Nat. Rev. Microbiol. 2004, 2, $123-140$. [CrossRef] [PubMed]

6. Frohlicher, E.; Krause, G.; Zweifel, C.; Beutin, L.; Stephan, R. Characterization of attaching and effacing Escherichia coli (AEEC) isolated from pigs and sheep. BMC Microbiol. 2008, 8, 144. [CrossRef] [PubMed] 
7. Kaur, P.; Chakraborti, A.; Asea, A. Enteroaggregative Escherichia coli: An emerging enteric food borne pathogen. Interdiscip. Perspect. Infect. Dis. 2010, 2010, 254159. [CrossRef] [PubMed]

8. Nguyen, Y.; Sperandio, V. Enterohemorrhagic E. coli (EHEC) pathogenesis. Front. Cell. Infect. Microbiol. 2012, 2, 90. [CrossRef]

9. Pitout, J.D.; Laupland, K.B. Extended-spectrum beta-lactamase-producing Enterobacteriaceae: An emerging public-health concern. Lancet Infect. Dis. 2008, 8, 159-166. [CrossRef]

10. Ibrahim, M.E.; Bilal, N.E.; Magzoub, M.A.; Hamid, M.E. Prevalence of extended-spectrum beta-lactamasesproducing escherichia coli from hospitals in Khartoum State, Sudan. Oman Med. J. 2013, 28, 116-120. [CrossRef]

11. Yano, H.; Uemura, M.; Endo, S.; Kanamori, H.; Inomata, S.; Kakuta, R.; Ichimura, S.; Ogawa, M.; Shimojima, M.; Ishibashi, N.; et al. Molecular characteristics of extended-spectrum beta-lactamases in clinical isolates from Escherichia coli at a Japanese tertiary hospital. PLoS ONE 2013, 8, e64359. [CrossRef]

12. Queenan, A.M.; Bush, K. Carbapenemases: The versatile beta-lactamases. Clin. Microbiol. Rev. 2007, 20, 440-458. [CrossRef] [PubMed]

13. Livermore, D.M. The impact of carbapenemases on antimicrobial development and therapy. Curr. Opin. Investig. Drugs 2002, 3, 218-224. [PubMed]

14. Hamelin, K.; Bruant, G.; El-Shaarawi, A.; Hill, S.; Edge, T.A.; Bekal, S.; Fairbrother, J.M.; Harel, J.; Maynard, C.; Masson, L.; et al. A virulence and antimicrobial resistance DNA microarray detects a high frequency of virulence genes in Escherichia coli isolates from Great Lakes recreational waters. Appl. Environ. Microbiol. 2006, 72, 4200-4206. [CrossRef] [PubMed]

15. Chen, B.; Zheng, W.; Yu, Y.; Huang, W.; Zheng, S.; Zhang, Y.; Guan, X.; Zhuang, Y.; Chen, N.; Topp, E. Class 1 integrons, selected virulence genes, and antibiotic resistance in Escherichia coli isolates from the Minjiang River, Fujian Province, China. Appl. Environ. Microbiol. 2011, 77, 148-155. [CrossRef] [PubMed]

16. Nontongana, N.; Sibanda, T.; Ngwenya, E.; Okoh, A.I. Prevalence and antibiogram profiling of Escherichia coli pathotypes isolated from the Kat River and the Fort Beaufort abstraction water. Int. J. Environ. Res. Public Health 2014, 11, 8213-8227. [CrossRef]

17. Franz, E.; Veenman, C.; van Hoek, A.H.; de Roda Husman, A.; Blaak, H. Pathogenic escherichia coli producing extended-spectrum beta-lactamases isolated from surface water and wastewater. Sci. Rep. 2015, 5, 14372. [CrossRef] [PubMed]

18. Tissera, S.; Lee, S.M. Isolation of Extended Spectrum beta-lactamase (ESBL) producing bacteria from urban surface waters in Malaysia. Malays. J. Med. Sci. 2013, 20, 14-22. [PubMed]

19. Talukdar, P.K.; Rahman, M.; Rahman, M.; Nabi, A.; Islam, Z.; Hoque, M.M.; Endtz, H.P.; Islam, M.A. Antimicrobial resistance, virulence factors and genetic diversity of Escherichia coli isolates from household water supply in Dhaka, Bangladesh. PLoS ONE 2013, 8, e61090. [CrossRef]

20. Ghorbani-Dalini, S.; Kargar, M.; Doosti, A.; Abbasi, P.; Sarshar, M. Molecular epidemiology of ESBL genes and multi-drug resistance in diarrheagenic escherichia coli strains isolated from adults in Iran. Iran. J. Pharm. Res. 2015, 14, 1257-1262.

21. Rashid, M.; Rakib, M.M.; Hasan, B. Antimicrobial-resistant and ESBL-producing Escherichia coli in different ecological niches in Bangladesh. Infect. Ecol. Epidemiol. 2015, 5, 26712. [CrossRef]

22. Nimri, L. First report of multidrug-resistant ESBL-producing urinary escherichia coli in Jordan. Br. Microbiol. Res. J. 2012, 2, 71-81. [CrossRef]

23. Kumar, D.; Singh, A.K.; Ali, M.R.; Chander, Y. Antimicrobial susceptibility profile of extended spectrum beta-lactamase (ESBL) producing escherichia coli from various clinical samples. Infect. Dis. 2014, 7, 1-8. [CrossRef]

24. Sid Ahmed, M.A.; Bansal, D.; Acharya, A.; Elmi, A.A.; Hamid, J.M.; Sid Ahmed, A.M.; Chandra, P.; Ibrahim, E.; Sultan, A.A.; Doiphode, S.; et al. Antimicrobial susceptibility and molecular epidemiology of extended-spectrum beta-lactamase-producing Enterobacteriaceae from intensive care units at Hamad Medical Corporation, Qatar. Antimicrob. Resist. Infect. Control 2016, 5, 4. [CrossRef] [PubMed]

25. Behrooozi, A.; Rahbar, M.; Jalil, V. Frequency of extended spectrum beta-lactamase (ESBLs) producing Escherichia coli and Klebseilla pneumonia isolated from urine in an Iranian 1000-bed tertiary care hospital. Afr. J. Microbiol. Res. 2010, 4, 881-884. 
26. Al Muharrmi, Z.; Rafay, A.M.; Balkhair, A.; Al-Tamemi, S.; Al Mawali, A.; Al Sadiri, H. Extended-spectrum beta-lactamase (ESBL) in omani children: Study of prevalence, risk factors and clinical outcomes at Sultan Qaboos University Hospital, Sultanate of Oman. Sultan Qaboos Univ. Med. J. 2008, 8, 171-177. [PubMed]

27. Jeong, S.H.; Bae, I.K.; Lee, J.H.; Sohn, S.G.; Kang, G.H.; Jeon, G.J.; Kim, Y.H.; Jeong, B.C.; Lee, S.H. Molecular characterization of extended-spectrum beta-lactamases produced by clinical isolates of Klebsiella pneumoniae and Escherichia coli from a Korean nationwide survey. J. Clin. Microbiol. 2004, 42, 2902-2906. [CrossRef]

28. Tamma, P.D.; Opene, B.N.; Gluck, A.; Chambers, K.K.; Carroll, K.C.; Simner, P.J. Comparison of 11 Phenotypic Assays for Accurate Detection of Carbapenemase-Producing Enterobacteriaceae. J. Clin. Microbiol. 2017, 55, 1046-1055. [CrossRef]

29. Salem, S.E.; Dahdouh, E.; Daoud, Z. Resistance of gram-negative bacilli in Lebanon. ISRN Infect. Dis. 2013, 2013, 759208. [CrossRef]

30. Bedenic, B.; Plecko, V.; Sardelic, S.; Uzunovic, S.; Godic Torkar, K. Carbapenemases in gram-negative bacteria: Laboratory detection and clinical significance. Biomed. Res. Int. 2014, 2014, 841951. [CrossRef]

31. Zahedi Bialvaei, A.; Samadi Kafil, H.; Ebrahimzadeh Leylabadlo, H.; Asgharzadeh, M.; Aghazadeh, M. Dissemination of carbapenemases producing Gram negative bacteria in the Middle East. Iran. J. Microbiol. 2015, 7, 226-246.

32. Hu, Y.Y.; Cai, J.C.; Zhou, H.W.; Chi, D.; Zhang, X.F.; Chen, W.L.; Zhang, R.; Chen, G.X. Molecular typing of CTX-M-producing escherichia coli isolates from environmental water, swine feces, specimens from healthy humans, and human patients. Appl. Environ. Microbiol. 2013, 79, 5988-5996. [CrossRef] [PubMed]

33. Amine, A. Extended spectrum beta-lactamase producing bacteria in waste water alexandria, Egypt. Int. J. Biosci. Biochem. Bioinform. 2013, 3, 605-608. [CrossRef]

34. Salah, M.; Badran, E.; Shehabi, A. High incidence of multidrug resistant Escherichia coli producing CTX-M-type ESBLs colonizing the intestine of Jordanian infants. Int. Arabic J. Antimicrob. Agents 2014, 3. Available online: http://www.imed.pub/ojs/index.php/IAJAA/article/view/811 (accessed on 5 May 2019).

35. Beceiro, A.; Tomas, M.; Bou, G. Antimicrobial resistance and virulence: A successful or deleterious association in the bacterial world? Clin. Microbiol. Rev. 2013, 26, 185-230. [CrossRef]

36. Ishii, Y.; Kimura, S.; Alba, J.; Shiroto, K.; Otsuka, M.; Hashizume, N.; Tamura, K.; Yamaguchi, K. Extended-spectrum beta-lactamase-producing Shiga toxin gene (Stx1)-positive Escherichia coli O26:H11: A new concern. J. Clin. Microbiol. 2005, 43, 1072-1075. [CrossRef] [PubMed]

37. Valat, C.; Haenni, M.; Saras, E.; Auvray, F.; Forest, K.; Oswald, E.; Madec, J.Y. CTX-M-15 extended-spectrum beta-lactamase in a shiga toxin-producing Escherichia coli isolate of serotype O111:H8. Appl. Environ. Microbiol. 2012, 78, 1308-1309. [CrossRef] [PubMed]

38. Khoshvaght, H.; Haghi, F.; Zeighami, H. Extended spectrum betalactamase producing Enteroaggregative Escherichia coli from young children in Iran. Gastroenterol. Hepatol. Bed Bench 2014, 7, 131-136. [PubMed]

39. Chen, Y.T.; Lin, J.C.; Fung, C.P.; Lu, P.L.; Chuang, Y.C.; Wu, T.L.; Siu, L.K. KPC-2-encoding plasmids from Escherichia coli and Klebsiella pneumoniae in Taiwan. J. Antimicrob. Chemother. 2014, 69, 628-631. [CrossRef]

40. Pournaras, S.; Poulou, A.; Voulgari, E.; Vrioni, G.; Kristo, I.; Tsakris, A. Detection of the new metallo-betalactamase VIM-19 along with KPC-2, CMY-2 and CTX-M-15 in Klebsiella pneumoniae. J. Antimicrob. Chemother. 2010, 65, 1604-1607. [CrossRef]

41. Jan, N.; Meshram, S.; Kulkarni, A. Plasmid profile analysis of multidrug resistant E. coli isolated from UTI patients of Nagpur City, India. Rom. Biotechnol. Lett. 2009, 14, 4635-4640.

42. Alam, M.; Rahman, M.; Siddique, M.; Khan, M.; Rahman, M. Antibiogram and plasmid profiling of E. coli isolates. Int. J. BioRes. 2010, 1, 1-7.

43. Gohar, M.; Sheikh, A.; Anjum, A.; Hussain, T.; Muhammad, J.; Tabbassum, A.; Kanwal, A.; Safdar, A. Plasmid profiling and curing of multidrug resistant Escherichia coli recovered from retail chicken meat. JAPS J. Anim. Plant Sci. 2015, 25, 984-988.

44. Al-Bahry, S.N.; Al-Mashani, B.M.; Elshafie, A.E.; Pathare, N.; Al-Harthy, A.H. Plasmid profile of antibiotic resistant Escherichia coli isolated from chicken intestines. J. Alabama. Acad. Sci. 2006, 77, 152-159.

45. Avşar, C.; Berber, İ. Plasmid profiling and antibiotics resisitance of Escherichia coli strains isolated from Mytilus galloprovincialis and seawater. J. Coast. Life Med. 2014, 2, 689-693. [CrossRef]

46. Amjad, A.; Mirza, I.; Abbasi, S.; Farwa, U.; Malik, N.; Zia, F. Modified Hodge test: A simple and effective test for detection of carbapenemase production. Iran. J. Microbiol. 2011, 3, 189-193. [PubMed] 
47. Chen, J.; Griffiths, M.W. PCR differentiation of Escherichia coli from other gram-negative bacteria using primers derived from the nucleotide sequences flanking the gene encoding the universal stress protein. Lett. Appl. Microbiol. 1998, 27, 369-371. [CrossRef] [PubMed]

48. Islam, M.A.; Heuvelink, A.E.; de Boer, E.; Sturm, P.D.; Beumer, R.R.; Zwietering, M.H.; Faruque, A.S.; Haque, R.; Sack, D.A.; Talukder, K.A. Shiga toxin-producing Escherichia coli isolated from patients with diarrhoea in Bangladesh. J. Med. Microbiol. 2007, 56, 380-385. [CrossRef]

49. Poirel, L.; Walsh, T.R.; Cuvillier, V.; Nordmann, P. Multiplex PCR for detection of acquired carbapenemase genes. Diagn. Microbiol. Infect. Dis. 2011, 70, 119-123. [CrossRef]

50. Nakhaei Moghaddam, M.; Forghanifard, M.M.; Moshrefi, S. Prevalence and molecular characterization of plasmid-mediated extended-spectrum beta-lactamase Genes (balaTEM, blaCTX and blASHV) among urinary escherichia coli clinical isolates in Mashhad, Iran. Iran. J. Basic Med. Sci. 2012, 15, 833-839.

(C) 2019 by the authors. Licensee MDPI, Basel, Switzerland. This article is an open access article distributed under the terms and conditions of the Creative Commons Attribution (CC BY) license (http://creativecommons.org/licenses/by/4.0/). 